\title{
Properties of pseudocereals, selected specialty cereals and legumes for food processing with special attention to gluten-free products
}

\section{Verarbeitungseigenschaften von Pseudogetreide, ausgewählten Spezialitätengetreide und Leguminosen mit speziellem Fokuss auf glutenfreie Produkte}

\begin{abstract}
Regine Schoenlechner ${ }^{1}$
${ }^{1}$ Institute of Food Technology, Department of Food Science and Technology, University of Natural Resources and Life Sciences, Vienna (BOKU), Muthgasse 18, 1190 Wien, Austria, email: regine.schoenlechner@boku.ac.at

Received: 13 October 2016, received in revised form: 9 December 2016, accepted: 9 December 2016

Summary

Cereals and legumes offer many nutritional benefits, and should therefore be consumed widely. In particular, legume consumption is very low in northern countries. Although many species of cereals, pseudocereals and legumes are available for human nutrition, today only a limited range of them is used in larger amounts. Wheat, rice and maize are dominating the cereal sector and beans, chickpeas and peas are the most produced legumes. Specialty cereals (e.g., colored varieties), pseudocereals (amaranth, quinoa, buckwheat) and legumes show great potential for the development of new food products due to their good nutritional composition and different functional properties.
\end{abstract}

Keywords: pseudocereals, legumes, gluten-free, chemical composition, nutritional properties

\section{Zusammenfassung}

Getreide und Hülsenfrüchte bieten viele ernährungsphysiologische Vorteile und sollten daher sehr häufig verzehrt werden. Besonders der Konsum von Hülsenfrüchten ist in den Ländern des Nordens sehr niedrig. Obwohl eine Vielzahl an Getreide-, Pseudogetreide- und Hülsenfrüchtearten und -sorten für die Humanernährung verfügbar wären, schränkt sich heute die Nutzung auf wenige Arten ein. Weizen, Reis und Mais dominieren den Getreidesektor und Bohnen, Kichererbsen und Erbsen sind die meist produzierten Hülsenfrüchte. Spezialitätengetreide (z.B. gefärbte Getreidesorten), Pseudogetreide (Amaranth, Quinoa, Buchweizen) und Hülsenfreüchte zeigen aufgrund ihrer guten ernährungsphysiologischen Zusammensetzung und unterschiedlichen funktionellen Eigenschaften ein sehr großes Protential für die Entwicklung neuer Nahrungsmittel.

Schlagworte: Pseudogetreide, Leguminosen, glutenfrei, chemische Zusammensetzung, ernährungsphysiologischen Eigenschaften 


\section{Introduction}

Cereal-based foods form the basis of human nutrition world-wide. Their main task is the supply of nutrition energy as they are rich in high polymer carbohydrates, mainly starch. Besides, cereals can and do contribute a significant amount of biologically active constituents that promote beneficial physiological effects like dietary fiber and their fractions, vitamins and polyphenols, to name only a few. There is a large variety of cereal species that has been and could be used for human nutrition, as well as starch-rich seeds that can be used like cereals, the co-called pseudocereals. Yet today, the production and consumption of cereal species and other starch-rich plants is dominated by only three species, namely wheat, rice and maize (FAOSTAT, 2016). This tendency cannot be seen positively for many obvious reasons, in particular, as appropriate alternatives are available. Alternative or specialty cereal species, pseudocereals and other starch-rich plants show great potential for the development of new food products. First of all, their good nutritional composition in comparison to the named major cereals has to be pointed out. Major cereals have undergone many centuries of breeding. The aim of these breeding programs have mainly been the increase in yield or disease resistance. Regarding the composition and nutritional quality, the focus has been and continues to be on the major components protein and starch, and less attention is paid to the secondary substances such as dietary fiber, polyphenols, phytate or ash. These latter mentioned components were even targets of reduction or elimination, because of adverse effects on quality when present in too high amounts. Only recently, it has been recognized that in a respective dose they can promote human health (decrease chronic diseases, etc.). Specialty cereals show differences in nutritional composition, in dietary fiber fractions, in polyphenols, as well as in mineral, vitamin, protein and amino acid composition. Often they have a high level of these functional components (Abdel-Aal and Wood, 2004).

The non-major cereal species are categorized under various terms: minor cereals, underutilized species, and alternative or specialty cereals (Abdel-Aal and Wood, 2004). While the first two names refer to their low production and consumption amount, the last one gives these species credit for their nutritional importance. Throughout this work, the term specialty cereals has been used.

The pseudocereals amaranth and quinoa were one of the major crops for the Pre-Colombian cultures in LatinAmerica, but the consumption and cultivation was sup- pressed after the Spanish conquest. In the mid 1990s, their good nutritional properties were recognized again, in particular their suitability for gluten-free food products. Thus, their production has increased again. The origin of buckwheat is middle Asia. In the $13^{\text {th }}$ century, it was transferred by nomadic people to middle Europe (Germany, Austria, Italy). Due to the importance of major cereals, its cultivation was decreased in the course of time, but like amaranth and quinoa, it is gluten-free and thus, receives increased attention again.

From a nutritional viewpoint, legumes are an important food source, but their consumption has declined immensely in the last few decades (most likely due to increased meat consumption). While in humans, nutrition like cereals and pseudocereals play a key role in providing energy due to the high amounts of starch in them; legumes are estimated in particular to have high amounts of proteins. Nutrition reports show that Austrians consume legumes only once in two months (Elmadfa et al., 2008). By developing palatable products enriched with legumes, the trend of decreasing consumption of legumes could be stopped. For consumers, easy-to-prepare or even ready-to-eat products (high degree of convenience) would be the simplest way to increase the consumption of legumes again.

\section{Botanical classification}

In Table 1, the botanical classification of cereals is shown. All cereal species belong to the family Poaceae (Gramineae) and are monocotyledonous. Within each genus, there are a large number of species, for example the colored and pigmented varieties like blue, purple or black wheat, barley or maize varieties, but these are only grown in small amounts. Within major cereal, there is a strong tendency to grow only a few species on the industrial scaled farms. Little used Triticum species are einkorn wheat (T. monococcum L.), emmer (T. dicoccum SCHRANK) spelt wheat (T. aestivum subsp. Spelta L.), khorasan wheat ("Kamut", T. turanicum JAKUBZ) and triticale (X Triticosecale Wittmack). Wheat and rye are also often referred to as bread cereals, as the leavened bread can be produced only from these two major cereals.

Besides these "true" cereals, there is another group of plants that produces starch-rich grains, which can be used like cereals. Botanically, they are assigned to the dicotyledonous plants and according to most researchers, they are summarized under the term pseudocereals. Although there are sev- 
Table 1. Botanical classification of cereals

Tabelle 1. Botanische Einteilung von Getreide

\begin{tabular}{|c|c|c|c|c|c|c|c|}
\hline Class & Monocotyledonae & & & & & & \\
\hline Order & Poales & & & & & & \\
\hline Family & Poaceae & & & & & & \\
\hline Subfamily & Pooidae & & & & Oryzoideae & Panicoideae & Andropo-gonodeae \\
\hline Tribus & Triticeae & & & Avenae & Oryzeae & Paniceae & Zeeae \\
\hline Genus & Triticum (wheat) & Secale (rye) & Hordeum (barley) & Avena (oat) & Oryza (rice) & Pennisetum (millet) & Zea (maize) \\
\hline
\end{tabular}

eral plants under this group, only three have gained some importance, namely amaranth, quinoa (see Figure 1) and buckwheat. In Table 2, their botanical classification is presented. According to several phylogenetic classifications, the Amaranthus and Chenopodium genus belong together to the Caryophyllales, whereas buckwheat (Fagopyrum) belongs to the Polygonales. Polygonales and Caryphyllales are closely related and are combined together in Caryophyllidae. However, the data obtained by Drzewiecki et al. (2003) indicate the occurrence of significant genetic distance between
Polygonales and Caryphyllales, and have been confirmed by Gorinstein et al. (2005). It seems that quinoa, buckwheat and amaranth (as a genus) can be considered as phylogenetic distant taxa, although according to Aphalo et al. (2004) the polymerized $11 \mathrm{~S}$ amaranth globulin (Globulin-P) presented cross-reactivity with quinoa globulins, and to a lesser extent with globulins of sunflower and rice. Worldwide more than 60 species of amaranth exist. The main grain amaranth species used today are Amaranthus caudatus L. (syn. Edulis Spegazzini), Amaranthus cruentus L. (syn. Paniculatus L.)

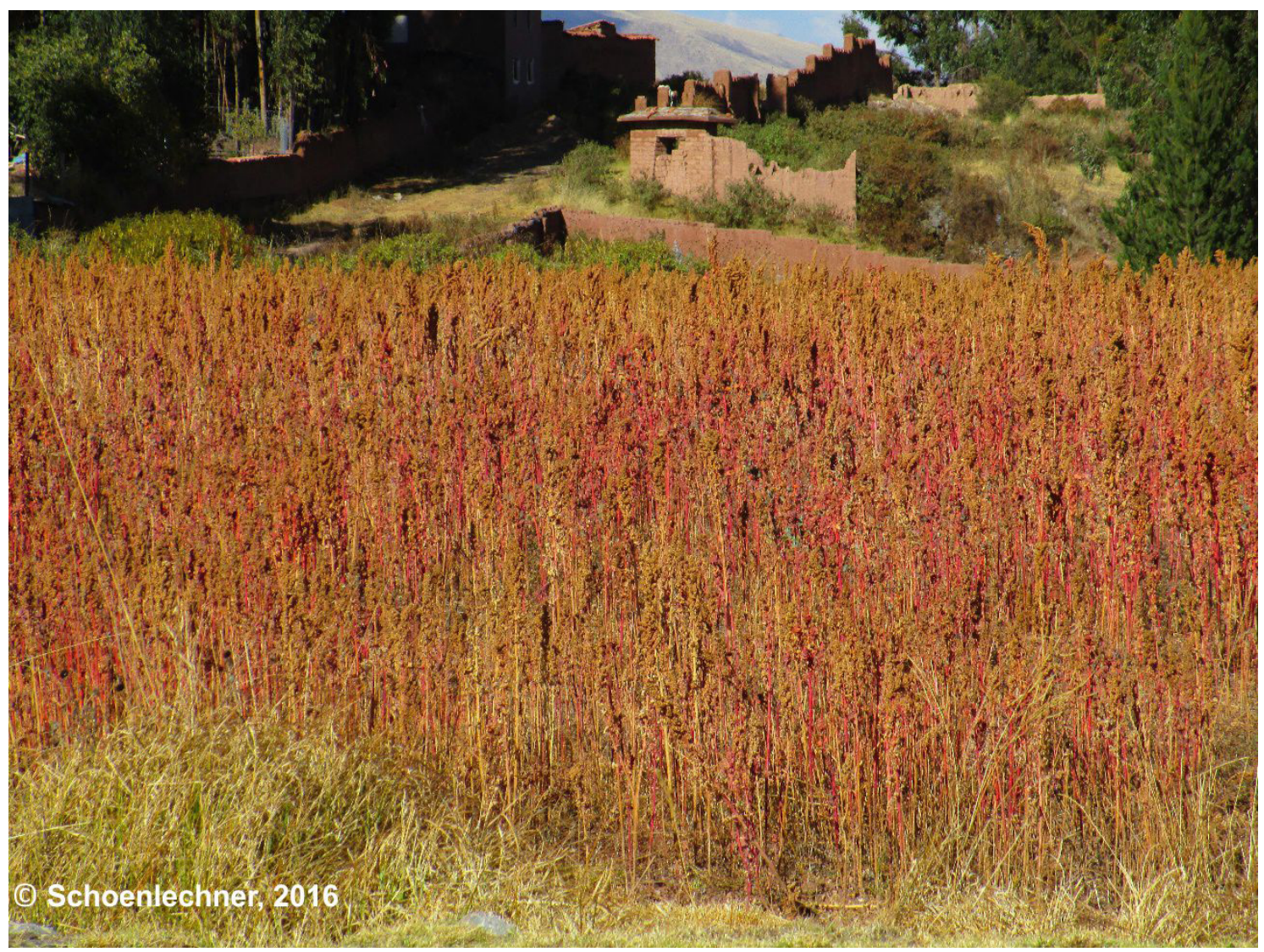

Figure 1. Quinoa field in Peru (yellow quinoa varieties) Abbildung 1. Quinoafeld in Peru (gelbe Quinoa-Sorten) 
Table 2. Botanical classification of pseudocereals (Amaranth, Quinoa, Buckwheat)

Tabelle 2. Botanische Einteilung von Pseudogetreide (Amaranth, Quinoa, Buchweizen)

\begin{tabular}{|c|c|c|c|}
\hline Class & & Dicotyledoneae & \\
\hline Subclass & & Caryophyllidae & \\
\hline Order & & hyllales & Polygonales \\
\hline Family & Amaranthaceae & Chenopodiaceae & Polygonaceae \\
\hline Genus & Amaranthus & Chenopodium & Fagopyrum \\
\hline Species & $\begin{array}{l}\text { at least } 60 \text { species, e.g.: } \\
\text { A. caudatus } \\
\text { A. cruentus } \\
\text { A. hypochondriacus }\end{array}$ & $\begin{array}{l}\text { more than } 250 \text { species, e.g.: Ch. quinoa } \\
\text { WILLD. (quinoa) } \\
\text { Ch. pallidicaule AELLEN } \\
\text { (kanigua, canihua) } \\
\text { Ch. nuttalia SAFFORD }\end{array}$ & $\begin{array}{l}\text { F. tartaricum } \\
\text { (bitter buckwheat) } \\
\text { F. esculentum } \mathrm{MOENCH} \\
\text { (sweet buckwheat) }\end{array}$ \\
\hline
\end{tabular}

and Amaranthus hypochondriacus L. Among quinoa, sweet and bitter varieties exist, which is dependent on the content of saponins; that is if the saponin content is below $0.11 \%$, the variety is considered as being a sweet variety (Koziol, 1991). Amaranth seeds are lentil-shaped and measure about $1 \mathrm{~mm}$ in diameter. The thousand kernel weight is only $0.5-$ 1.4 g. Quinoa seeds are slightly bigger than amaranth; the thousand kernel weight is approximately 1.9-4.3 g. In contrast to cereals, the embryo surrounds the starch-rich tissue (perisperm) in the form of a ring and makes about $25 \%$ of the total seed weight.

Table 3. Production of cereals worldwide in the year 2014 (latest available data; FAOSTAT, 2016)

Tabelle 3. Weltweite Getreideproduktion im Jahr 2014 (letzte verfügbare Daten; FAOSTAT, 2016)

\begin{tabular}{lcc}
\hline Item & World production $(\mathrm{mt})$ & \% of total production \\
\hline Maize & 1038.28 & 36.85 \\
Rice, paddy & 728.97 & 25.87 \\
Wheat & 740.96 & 26.30 \\
Barley & 144.33 & 5.12 \\
Sorghum & 67.87 & 2.41 \\
Millet & 27.83 & 0.99 \\
Oat & 22.97 & 0.82 \\
Triticale & 15.34 & 0.54 \\
Rye & 17.07 & 0.61 \\
Cereals, nes & 3.74 & 0.13 \\
Mixed grain & 6.87 & 0.24 \\
Buckwheat & 2.06 & 0.07 \\
Fonio & 0.66 & 0.02 \\
Canary seed & 0.20 & 0.01 \\
Quinoa & 0.19 & 0.01 \\
\hline \multicolumn{1}{c}{ Sum } & 2817.33 & 100 \\
\hline
\end{tabular}

Two varieties of buckwheat are commonly cultivated: common buckwheat (Fagopyrum esculentum) and Tartary buckwheat (Fagopyrum tataricum). The buckwheat seed is a three-angled achene, 6-9 mm long. The fruit of F. tataricum is smaller $(4-5 \mathrm{~mm})$ and more rounded at the edges. The thousand kernel weight (10-20 g) depends mainly on the hull thickness. Structurally and chemically, the endosperm resembles that of a cereal grain consisting of a nonstarchy aleurone layer and large cells packed with starch granules constituting the majority of the endosperm.

Legumes belong to the botanical family Fabaceae or Leguminosae, commonly known as the legume, pea, or bean family. They are a large and economically important family of flowering plants. The group is the third-largest land plant

Table 4. Production of pulses (legumes) worldwide in the year 2014 (latest available data; FAOSTAT, 2016)

Tabelle 4. Weltweite Produktion von Körnerleguminosen im Jahr 2014 (letzte verfügbare Daten; FAOSTAT, 2016)

\begin{tabular}{lcc}
\hline Item & $\begin{array}{c}\text { World production }(\mathrm{mt}) \\
\text { 2014 }\end{array}$ & \% of total production \\
\hline Beans, dry & 25.09 & 32.34 \\
Chick peas & 14.24 & 18.35 \\
Peas, dry & 11.33 & 14.60 \\
Cow peas, dry & 5.59 & 7.20 \\
Lentils & 4.89 & 6.30 \\
Pigeon peas & 4.86 & 6.26 \\
Broad beans, horse & 4.30 & \\
beans, dry & & 5.54 \\
Pulses, nes & 5.15 & 6.64 \\
Lupines & 0.98 & 1.26 \\
Vetches & 0.88 & 1.14 \\
Bambara beans & 0.29 & 0.37 \\
\hline \multicolumn{1}{c}{ Sum } & 77.60 & 100 \\
\hline
\end{tabular}


family, with about 730 genera and over 19400 species. The most important ones are beans (Phaesolus sp., Vicia sp.), peas (Pisum sp.), chickpeas (Cicer arietinum L.), cow peas (Vigna unguiculata), lentils (Lens sp.) and lupines (Lupinus sp.).

\section{Production data and importance}

The FAO Statistic Division gives production data for all major and some minor cereals species, as well as pulses (legumes) (FAOSTAT, 2016). In Table 3, the production data of cereals in the year 2014 (latest available data by FAOSTAT, 2016) is summarized, Table 4 shows the production data for pulses. The data for cereals demonstrate clearly the dominance of the three major cereals maize, wheat and rice; these are all produced in amounts higher than 7 billion tons worldwide. Together they make $89.02 \%$ of the total cereal production. Compared to these three cereal species, barley is of much less importance but still more than $144 \mathrm{mt}$ are produced (5\% of total cereal production), most of which is used for the brewing industry. Thus, barley is also considered as one of the major cereals, although it is hardly used in the baking industry anymore. As described before, apart from these major cereal species, there are many more cereal species that are used for human nutrition, but they are only used in small amounts. All these species together make only $10.98 \%$ of the total cereal production. Besides the named major cereals, the FAO Statistic Division lists the following additional species: sorghum, millet, fonio, canary seed, oat, triticale, rye, buckwheat and quinoa. Amaranth, as being another important specialty cereal, is not listed; thus, no produc- tion data are available. Additionally, there is no detailed information on the used species, so from these statistics it cannot be estimated in what amounts are the specialty cereals grown within the major cereals (e.g., colored or pigmented wheat, barley, maize species, einkorn wheat, emmer or spelt wheat).

Within the legume species, beans are the most produced leguminous species in the world, followed by chickpeas and peas (FAOSTAT, 2016). Beans are an important crop in Latin America, where its consumption has a long tradition. The combination of maize and beans was the basis of nutrition since many centuries and in some countries, this tradition has remained (e.g., Mexico). Chickpeas are an important crop in parts of Asia and the Mediterranean region of Europe and Africa and are used in the preparation of a variety of snacks (Annapure et al., 1998).

\section{Chemical and nutritional properties}

The chemical composition of any grown plant raw material is influenced by species or genotype, growing environment and cultural conditions (e.g., fertilization, soil, etc.). This makes the comparison of various cereal species difficult. Another fact is that there are different analytical methods to determine the composition, which lead to different results. This is in particular true for the determination of dietary fiber. Determination of dietary fiber is at present much discussed and the available methods result in highly different values. Considering these facts, caution has to be taken to compare data from literature. In Table 5, the average values have been collected for gross chemical

Table 5. Chemical composition of selected cereals (Souci et al., 2013) (values given in g/100g dry matter)

Tabelle 5. Chemische Zusammensetzung von ausgewählten Getreidearten (Souci et al., 2013) (Werte in g/100g Trockenmasse)

\begin{tabular}{lccccccccccccc}
\hline & Wheat & $\begin{array}{c}\text { Spelt } \\
\text { wheat }\end{array}$ & Rye & Triticale & Barley & $\begin{array}{l}\text { Rice (not } \\
\text { polished) }\end{array}$ & $\begin{array}{c}\text { Oat } \\
\text { (de-husked) }\end{array}$ & Maize & Millet & Sorghum Amaranth Quinoa & $\begin{array}{c}\text { Buck- } \\
\text { wheat }\end{array}$ \\
\hline Protein $(\mathrm{N} \times 5.8)$ & 12.20 & 17.64 & 10.22 & 14.12 & 11.84 & 8.31 & 11.52 & 9.51 & 11.19 & 11.62 & 17.49 & 15.74 & 11.04 \\
Fat & 2.11 & 1.89 & 1.97 & 2.85 & 2.39 & 2.53 & 9.18 & 4.35 & 4.43 & 3.61 & 10.56 & 6.16 & 1.97 \\
Carbohydrates $^{\mathrm{a}}$ & 68.49 & 67.31 & 70.32 & 73.14 & 72.05 & 85.24 & 64.74 & 73.53 & 78.24 & 78.62 & $68.06^{\mathrm{b}}$ & 66.73 & 80.82 \\
Dietary fiber & $15.31^{\mathrm{c}}$ & $11.12^{\mathrm{c}}$ & $15.29^{\mathrm{d}}$ & $7.74^{\mathrm{e}}$ & $11.16^{\mathrm{d}}$ & $2.54^{\mathrm{c}}$ & $11.24^{\mathrm{c}}$ & $11.12^{\mathrm{c}}$ & $4.32^{\mathrm{d}}$ & $4.17^{\mathrm{c}}$ & $11.14^{\mathrm{f}}$ & $12.88^{\mathrm{f}}$ & $8.62^{\mathrm{f}}$ \\
Ash & 1.90 & 2.04 & 2.20 & 2.15 & 2.56 & 1.38 & 3.31 & 1.49 & 1.82 & 1.97 & 3.89 & 3.80 & 1.96 \\
\hline
\end{tabular}

${ }^{a}$ Estimated by the difference method: $100-($ water + protein $(\mathrm{N} \times 5.8)+$ fat + minerals + total dietary fiber $)$

b Sum starch + sucrose + maltose

${ }^{c}$ Modified AOAC method (no further information given, but assumable AOAC 985.29)

d Method of Meuser, Suckow and Kulikowski ("Berliner Methode") (Meuser et al., 1983)

e Method unknown

${ }^{\mathrm{f}}$ Own measurements: AOAC 985.29 (total dietary fiber) 
composition of selected cereal species. Table 6 summarizes these data for selected legumes. For an overview, most data were derived from the food and nutrition tables of Souci et al. $(2008 ; 2013)$, who collect data from literature and try to consider the methods applied for the determination of relevant constituent. In their original tables, they give the range of data found, as well as the average value. In this work, only the average value was taken. For dietary fiber, the applied method was mentioned in a footnote to the table. Missing data were complemented by additional data from own measurements (where marked).

The most abundant constituents found in cereals are carbohydrates in the form of starch and proteins. Differences between the species exist. Rice, millet and sorghum contain higher amounts of starch, while oat, amaranth and quinoa have lower amounts than wheat, maize, barley or rye. Spelt wheat, amaranth and quinoa show the highest content of protein; the fat content is highest in amaranth, oat and quinoa. The nutritional value of pseudocereals is mainly connected to their protein content. While alcohol-soluble prolamins represent the major storage proteins in cereals such as wheat or maize, the storage proteins of dicotyledonous plants are mainly globulins and albumins (Gorinstein et al., 2002; Drzewiecki et al., 2003). The amino acids composition in pseudocereals is excellent, with a high content of essential amino acids. In particular, methionine, lysine, arginine, tryptophan and sulphur-containing amino acids are found in higher amounts than in other cereals (Matuz et al., 2000; Gorinstein et al., 2002). Immunological studies have shown that amaranth and quinoa do not contain toxic proteins to coeliac disease patients and can thus be used within a gluten-free diet (Hibi et al., 2003; Bergamo et al., 2011). Relevant for health promoting benefits within cereals are in particular dietary fiber and its compounds (e.g., resistant starch, crude fiber, ß-glucan), polyphenols and some vitamins (e.g., folic acid). As here again different analytical methods are applied, it is difficult to compare data from the literature, also some of these data are not available or have a limited availability for specialty cereals or pseudocereals. Our own studies have been conducted to perform some of these analyses, applying the same method for the selected cereals. In comparison to cereal species, amaranth and quinoa contain a very high amount of folic acid (Schoenlechner et al., 2010).

Legumes contain about $20-30 \%$ protein. Its amino acid composition complements well with the one of cereals. The proteins of legumes are rich in lysine and deficient in sulphur containing amino acids, whereas cereal proteins are deficient in lysine, but have adequate amounts of sulphur amino acids (Eggum and Beame, 1983). The combination of grain and legume proteins thus provides better overall essential amino acid balance. Another advantage of legumes is their usually low content of fat $(0.6-5.5 \%$ in peas, about $1 \%$ in beans) and high content of minerals, trace elements and vitamins, in particular of B-group vitamins. The low glycaemic index, as well as the content of phytochemical substances, are the additional positive properties of legumes. The present oligosaccharides raffinose, stachyose and verbascose are connected to flatulence. By fermentation, germination or in lower amount also by soaking these oligosaccharides can be decreased. Their total removal is not advantageous, because these oligosaccharides also act as prebiotics.

\section{Food use}

In order to increase the range of used cereals and legumes for human consumption, appropriate food products have to be supplied to the consumers. As described above, all these cere-

Table 6. Chemical composition of selected legumes (Souci et al., 2008) (values given in g/100g dry matter)

Tabelle 6. Chemische Zusammensetzung von ausgewählten Leguminosenarten (Souci et al., 2013) (Werte in g/100g Trockenmasse)

\begin{tabular}{|c|c|c|c|c|c|}
\hline Component & Bean, dry & Chickpea, dry & Pea, dry & Cow pea, dry & Lentil, dry \\
\hline Protein $(\mathrm{N} \times 5.8)$ & 24.82 & 21.32 & 27.00 & 28.36 & 27.49 \\
\hline Fat & 1.90 & 6.78 & 1.70 & 1.71 & 1.88 \\
\hline Carbohydrates $^{\mathrm{b}}$ & 41.21 & 50.77 & 48.57 & 40.46 & 47.70 \\
\hline Dietary fiber ${ }^{c}$ & 27.55 & 17.76 & 19.57 & 25.18 & 19.97 \\
\hline Ash & 4.51 & 3.37 & 3.16 & 4.28 & 2.95 \\
\hline
\end{tabular}

a Phaseolus vulgaris

${ }^{\mathrm{b}}$ Estimated by the difference method: 100 - (water + protein $(\mathrm{N} \times 5.8)+$ fat + minerals + total dietary fiber $)$

${ }^{c}$ Modified AOAC method (no further information given, but assumable AOAC 985.29) 
al and pseudocereal varieties offer certain nutritional benefits; in particular, the pseudocereals have to be pointed out in this respect. For the production of gluten-free foods, they are of specific interest. Principally specialty cereals can be used for all food processes, but they often require certain adaptation of the recipe or processing conditions, in particular, when they are used as the sole cereal ingredient. Einkorn wheat for example has low gluten strength and rheological properties and thus, the resulting breads show decreased bread volume and crumb elasticity. Grausgruber et al. (2008) demonstrated that the application of individual enzymes and/or emulsifiers or their application in mixtures could significantly improve bread volume and crumb firmness of whole-grain einkorn breads. Special attention has to be paid to sensory properties of the food products developed from these rather unknown cereal varieties, as only highly palatable products will be accepted by the consumers. The taste of amaranth and quinoa is different from the common consumed cereal products. Popping or roasting the seeds prior to milling was shown to improve their palatability. To overcome these challenges, often cereals and pseudocereals are used in flour blends with wheat, which usually requires only minimum process adaption. A lot of research has been performed in this direction. Already a replacement of $10-20 \%$ wheat flour by these cereals or pseudocereals was shown to increase the nutritional properties of the resulting end-product and sometimes they were even preferred in sensory evolutions.

With respect to processing, one of the reasons why legumes are consumed in very low amounts today is that the preparation of legumes is time consuming, for example chickpeas need about 2 hours for cooking. Soaking in cold water over- night can decrease cooking time, but care has to be taken to avoid microbial growth. Thus, the supply of already prepared legume products could help to increase its food use, for example pre-cooked legumes. Although tinned products are not usually seen as a healthy option, today steam cooked beans or chickpeas can be found in the supermarket that are not only ready-to-heat, but also have an increased nutritional value and taste (see Figure 2). Another possibility to process legumes is to blend them with cereal flours in conventional products. Studies have shown that by the use of legumes, the sensory properties of final products are not adversely affected, sometimes texture can even be improved. In a study on cookies from wheat or gluten-free flours with chickpea, it was found that chickpea addition decreased the lightness in white wheat cookies while increasing it in whole wheat and amaranth cookies. It significantly increased yellowness in all the cookies. The spread factor of the glutenfree cookies was reduced by chickpea addition and the hardness was increased in white wheat and buckwheat cookies, and decreased in the whole wheat and amaranth cookies. Sensory evaluation demonstrated that chickpea addition increased the acceptability of all cookies, in particular of the gluten-free cookies. Optimal levels of chickpea addition were $20-40 \%$ in wheat cookies and $60-80 \%$ for amaranth and buckwheat cookies (Yamsaengsung et al., 2012). While the consumption and use of whole legumes is low in many Western countries, legumes are often used to obtain protein concentrates or isolates from plant origin. These are widely applied in the food industry, namely for texture improvement in bakery or dairy products, or as a major ingredient in meat substitute products.
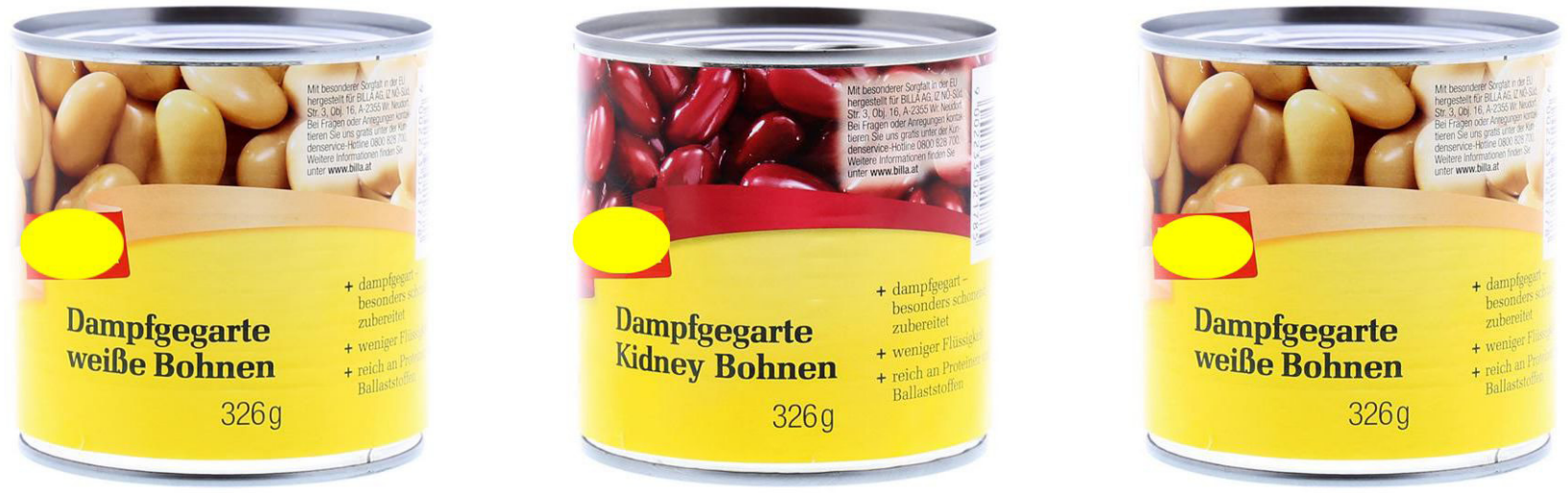

Figure 2. Commercially available steam cooked legumes (chickpeas, kidney beans, white beans) Abbildung 2. Kommerziell verfügbare dampfgegarte Körnerleguminosen (Kichererbsen, Kidneybohnen, Weiße Bohnen) 


\subsection{Gluten-free processing}

In the past years, gluten-free foods have been one of the most important driving forces for the increased interest in specialty cereals and pseudocereals. The demand for glutenfree products is caused by the fact that the occurrence of gluten-related disorders has increased. There are three main forms of gluten reactions: autoimmune (coeliac disease, dermatitis herpetiformis and gluten ataxia), allergic (wheat allergy) and possibly immune-mediated (non coeliac disease gluten or wheat sensitivity) (Sapone et al., 2012). Coeliac disease as one of the severest forms of gluten intolerance has moved from obscurity into the popular spotlight worldwide (Sapone et al., 2012). Figures for prevalence of coeliac disease (in particular in northern countries) are steadily increasing. Its mean prevalence is estimated to be $1-2 \%$ of the world population (Reilly and Green, 2012). Coeliac disease is a multisystemic autoimmune disease that causes smallintestinal mucosal injury, but also additional many other symptoms. Triggers for coeliac disease are certain epitopes of gluten and glutelin fractions that are found in all wheat, rye, barley and eventually oat species. Coealiac disease patients have to strictly exclude these cereals from their diet (Catassi and Yachha, 2009; Sapone et al., 2012).

The prevalence of wheat allergy is considered to be below 1\% worldwide (Sapone at al., 2012). Persons suffering from wheat allergy have to exclude wheat from their diet, but can include all other cereals. Non coeliac disease gluten or wheat sensitivity is a rather newly recognized disorder, and its prevalence is estimated to be up to $7 \%$ (Nejad et al., 2012). Affected persons suffer from gastroenterological symptoms similar to coeliac disease, although they are negatively diagnosed for coeliac disease. Triggers for this disorder are still not understood, which makes a clear clinical diagnosis difficult. ATIs (amylase-trypsin inhibitors) or FODMAPS (fermentable oligosaccharides) are currently under discussion to cause gluten sensitivity. At present, the treatment is also done by adhering to a gluten-free diet.

\subsection{Gluten-free bread and pasta}

Gluten-free processing is still a great challenge today. The main aim is to replace the three-dimensional network that is formed by gluten and is responsible for the texture in bread and pasta. This not only requires changes in the recipe, but also adaptions or modifications of processing properties. The use of isolated proteins of various origins to replace gluten has been studied intensively. Several legume proteins, for ex- ample from soy bean, pea, chickpea, or lupin can be used for this aim. An additional advantage of incorporating legumes into gluten-free products is that the amount of (prebiotic) dietary fiber, vitamins and minerals can be increased. Additionally, by combining cereal and legumes in one product, the final amino acid pattern will become more balanced.

Gluten-free bread baking differs greatly from conventional wheat or rye baking. Most important is the changed water content, which in some studies has been increased up to $100 \%$ of flour, compared to about $55-60 \%$ in wheat breads. Thus, for processing it has to be considered that gluten-free baking is done from batters rather than doughs. Research in the past decades has elaborated that a system of hydrocolloid-emulsifier-protein is able to produce acceptable bread quality. Also (crosslinking) enzymes might be used to support the processing properties, like the starchmodifying amylase, cyclodextrin glycosyltransferases, the protein-connecting transglutaminase, glucose oxidase, laccase or proteases (Goessart et al., 2008; Gallagher, 2009). Recently, the application of sourdough fermentation for gluten-free baking is pursued with more emphasis (Zannini et al., 2012; Picozzi et al., 2016,).

In gluten-free pasta, the function of gluten is mainly to achieve an elastic texture of pasta that do not disintegrate during cooking. One of the best substitute for gluten in pasta is the use of egg white protein. Other proteins like soy protein can also be used (Schoenlechner et al., 2010). Emulsifier addition supports the final pasta texture. Still these types of gluten-free pasta lack elasticity and thus, the typical pasta texture is missing. Research now puts its focus more on the role of starch within gluten-free pasta processing (Marti et al., 2011), or on the application of changed pasta processing technology. The use of pre-gelatinized flours, hot extrusion cooking or high temperature drying regimes are attempts in this direction (Marti et al., 2013; D'Amico et al., 2015). Most gluten-free pasta found in the market today are (still) based on maize starch.

The increasing need for gluten-free food products has caused the market to grow fast. Today, they are offered in almost all supermarkets, and owing to much research in the past, their quality is steadily increasing.

\section{Conclusion}

In conclusion, although specialty cereals, pseudocereals and legumes offer nutritional advantages, food products from these raw materials are still rarely offered. Research 
has demonstrated that these varieties are suitable for valueadded food products. Emphasis has to be laid on efforts to develop and produce sensory appealing food products, in order to encourage the consumption of a wider range of food products again.

\section{References}

Abdel-Aal E. and P. Wood (Eds.) (2004): Specialty grains for food and feed. AACC International Inc., St. Paul, Minnesota, USA.

D‘Amico, S., Maschle, J., Jekle, M., Tomoskozi, S., Lango, B. and R. Schoenlechner (2015): Effect of high temperature drying on gluten-free pasta properties. LWT - Food Science and Technology 63, 391-399.

Annapure, U.S., Singhal, R.S. and P.R. Kulkarni (1998): Studies on deep-fat fried snacks from some cereals and legume. Journal of Science of Food and Agriculture 76, 377-382.

Aphalo, P., Castellani, O.F., Martinez, E.N. and M.C. Anon (2004): Surface physiochemical properties of globulin-P amaranth protein. Journal of Agricultural and Food Chemistry 52, 616-622.

Bergamo, P., Maurano, F., Mazzarella, G., Iaquinto, G., Vocca, I., Rivelli, A.R., De Falco, E., Gianfrani, C. and M. Rossi (2011): Immunological evaluation of the alcohol-soluble protein fraction from gluten-free grains in relation to celiac disease. Molecular Nutrition and Food Research 55, 1266-1270.

Catassi, C. and S.K. Yachha (2009): The epidemiology of celiac disease. In: Arendt, E.K. and F. Dal Bello (Eds.): The Science of gluten-free foods and beverages. AACC International Inc., St. Paul, Minnesota, USA, 1-13.

Drzewiecki, J., Delgado-Licon, E., Haruenkit, R., Pawlezik, E., Martin-Belloso, O., Park, Y.S., Jung, S.T., Trakhtenberg, S. and S. Gorinstein (2003): Identification and differences of total proteins and their soluble fractions in some pseudocereals based on electrophoretic pattern. Journal of Agricultural and Food Chemistry $51,7798-7804$.

Eggum, B.O. and B.M. Beame (1983): The nutritive value of seed proteins. In: Gottschalk, W. and P.H. Müller (Eds.): Seed Protein Biochemistry, Genetics and Nutritive Value. Junk, The Hague, 499-531.

Elmadfa, I., Freisling, H., Novak, V. and D. Hofstädter (2008): Österreichischer Ernährungsbericht 2008. Robidruck, Wien.
FAOSTAT (2016): FAO Statistics Division 2014, http:// faostat.fao.org/. Updated: 16 January 2016.

Gallagher, E. (2009): Improving gluten-free bread quality through the application of enzymes. Agro Food Industry Hi-Tech 20, 34-37.

Gorinstein, S., Drzewiecki, J., Delgado-Licon, E., Pawelzik, E., Martinez Ayala, A.L., Medina, O.J., Haruenkit, R. and S. Trakhtenberg (2005): Relationship between dicotyledonae-amaranth, quinoa, fagopyrum, soybean and monocots- sorghum and rice based on protein analyses and their use as substitution of each other. European Food Research and Technology 221, 69-77.

Gorinstein, S., Pawelzik, E., Delgado-Licon, E., Haruenkit, R., Weisz, M. and S. Trakhtenberg (2002): Characterisation of pseudocereal and cereal proteins by protein and amino acid analyses. Journal of the Science of Food and Agriculture 82, 886-891.

Grausgruber, H., Miesenberger, S., Schoenlechner, R. and J. Vollmann (2008): Influence of dough improvers on whole-grain bread quality of einkorn wheat. Acta Alimentaria 37, 379-390.

Gross, R., Koch, F., Malaga, I., De Miranda, A.F., Schoeneberger, H. and L.C. Trugo (1989): Chemical composition and protein quality of some local Andean food sources. Food Chemistry 34, 25-34.

Hibi, M., Hachimura, S., Hashizume, S., Obata, T. and S. Kaminogawa (2003): Amaranth grain inhibits antigenspecific $\mathrm{IgE}$ production through augmentation of the IFN-y response in vivo and in vitro. Cytotechnology 43, 33-40.

Marti, A., Caramanico, R., Bottega, G. and M.A. Pagani (2013): Cooking behavior of rice pasta: Effect of thermal treatments and extrusion conditions. LWT - Food Science and Technology 54, 229-235.

Marti, A., Pagani, M.A. and K. Seetharaman (2011): Understanding starch organisation in gluten-free pasta from rice flour. Carbohydrate Polymers 84, 1069-1074.

Matuz, J., Bartok, T., Morocz-Salomon, K. and L. Bona (2000): Structure and potential allergenic character of cereal proteins: I. Protein content and amino acid composition. Cereal Research Communications 28, 263270.

Meuser, F., Suckow, P. and W. Kulikowski (1983): Analytische Bestimmung von Ballaststoffen in Brot, Obst und Gemüse. Getreide, Mehl und Brot 37, 380-383.

Nejad, M.R., Karkhane, M., Marzban, A., Mojarad, E.N. and K. Rostami (2012): Gluten related disorders. Gastroenterology and Hepatology from Bed to Bench 5, 1-7. 
Picozzi, C., Mariotti, M., Cappa, C., Tedesco, B., Vigentini, I., Foschino, R. and M. Lucisano (2016): Development of a Type I gluten-free sourdough. Letters in Applied Microbiology 62, 119-125.

Reilly, N.R. and P.H.R. Green (2012): Epidemiology and clinical presentations of celiac disease. Seminars in Immunopathology 34, 473-478.

Sapone, A., Bai, J., Ciacci, C., Dolinsek, J., Green, P.H.R., Hadjivassiliou, M., Kaukinen, K., Rostami, K., Sanders, D.S., Schumann, M., Ullrich, R., Villalta, D., Volta, U., Catassi, C. and A. Fasano (2012): Spectrum of glutenrelated disorders: Consensus on new nomenclature and classification. BMC Medicine 10, Article number 13.

Schoenlechner, R., Wendner, M., Siebenhandl-Ehn, S. and E. Berghofer (2010): Pseudocereals as alternative sources for high folate content in staple foods. Journal of Cereal Science 52, 475-479.

Schoenlechner, R., Mandala, I., Kiskini, A., Kostaropoulos, A. and E. Berghofer (2010): Effect of water, albumen and fat on the quality of gluten-free bread containing amaranth. International Journal of Food Science and Technology 45, 661-669.
Souci, S.W., Fachmann, W. and H. Kraut (2008): Food composition and nutrition tables. Wissenschaftliche Verlagsgesellschaft mbH, Stuttgart, Germany.

Souci, S.W., Fachmann, W. and H. Kraut (2013): Die Zusammensetzung der Lebensmittel, Nährwert-Tabellen. Medpharm Online Datenbank, http://www.sfkonline.net.

Tari, T.A., Annapure, U.S., Singhal, R.S. and P.R. Kulkarni (2003): Starch-based spherical aggregates: screening of small granule sized starches for entrapment of a model flavouring compound, vanillin. Carbohydrate Polymers 53, 45-51.

Yamsaengsung, R., Berghofer, E. and R. Schoenlechner (2012): Physical properties and sensory acceptability of cookies made from chickpea addition to white wheat or whole wheat flour compared to gluten-free amaranth or buckwheat flour. International Journal of Food Science and Technology 47, 2221-2227.

Zannini, E., Pontonio, E., Waters, D.M. and E.K. Arendt (2012): Applications of microbial fermentations for production of gluten-free products and perspectives. Applied Microbiology Biotechnology 93, 473-485. 